\title{
Moderate intensity aerobic exercise effects on the quality of life and general health
}

\section{Orta şiddetli aerobik egzersizin yaşam kalitesi ve genel sağlık üzerindeki etkileri}

\author{
Dilara Sak ${ }^{1}$ (D) Taygun Dayı $^{1}$ iD, Erkan Günay ${ }^{2}$ iD, Adile Öniz ${ }^{3}$ iD \\ ${ }^{1}$ Department of Nutrition and Dietetics, Faculty of Health Sciences, Near East University, Nicosia, Turkish Republic of Northern Cyprus \\ ${ }^{2}$ Department of Coaching Education, Necat Hepkon Faculty of Sport Sciences, Dokuz Eylül University, Izmir, Turkey \\ ${ }_{3}^{3}$ Dean, Faculty of Health Sciences, Near East University, Nicosia, Turkish Republic of Northern Cyprus
}

\section{ABSTRACT}

Objective: Effects of regular physical activity on the human health is an important factor for the life quality parameters. The present study aimed to determine effects of moderate aerobic exercise on the life quality and human health.

Materials and Methods: There were three groups (competitive cyclists, recreational cyclists and control) who voluntarily participated in this study. The cyclists of the National Bicycle Federation who could continue trainings during the Corona virus pandemic (n: 50 ), cyclists of the amateur clubs (n: 50) and 50 sedentary adults ( $\geq 19$ years) were enrolled (n:150). World Health Organization Quality of Life Questionnaire Abbreviated Version - WHOQOLBREF-TR was used to determine participants' life qualities.

Results: Competitive cyclists trained for $13.33( \pm 7.24)$ hours per week and they had 4798 min/week MET values. Subgroup scores of WHQOL-BREFTR (physical, psychological, social, environmental, national environment, general life quality and health) were found to be higher in competitive cyclists than others (recreational cyclists and sedentary adults). In addition, the values of competitive and amateur cyclists in the physical health level parameters were higher than the control group. Competitive cyclists had higher scores for psychological, social health and general life quality subgroups than others $(p<0.05)$.

Conclusion: The present study showed that if physical activity level increases, general health status and life quality increase. As a result of the study, it was found that moderate-intensity aerobic exercise (2600-4800 MET-min/week energy expenditure) between 7-13 hours a week supports the protection of general health and has positive effects on life quality. There is a need for future research to determine different exercise types, intensity, frequency and their effects on the general health status and life quality.

\section{Keywords: Aerobic exercise, health, life quality}

$\underline{o ̈ z}$

Amaç: Düzenli olarak yapılan fiziksel aktivite sağlık üzerinde önemli etkileri olan yaşam kalitesi belirleyicileri arasında yer almaktadır. Bu çalışmada orta şiddetli aerobik egzersizin yaşam kalitesi ve genel sağık üzerindeki etkilerinin belirlenmesi hedeflenmiştir.

Gereç ve Yöntem: Yerel Bisiklet Federasyonu'na bağlı olan ve pandemi döneminde de aktif olarak antrenman yapmaya devam eden yarışmacı bisikletçiler ( $n$ : 50), amatör kulüplere bağlı olan rekreasyonel bisikletçiler (n: 50) ve spor yapmayan sedanter bireyler (n: 50) olmak üzere üç grup, toplam 150 kişi ( $\geq 19$ yaş) gönüllü katılım göstermiştir. Bireylerin yaşam kalitesini belirlemede 'Dünya Sağlık Örgütü Yaşam Kalitesi Ölçeği Kısaltılmış Versiyonu (WHOQOL-BREF-TR)' kullanıımıştır.

Bulgular: Haftada 13.33 ( \pm 7.24$)$ saat antrenman yapan yarışmacı bisikletçilerin MET değerlerinin $4798 \mathrm{MET}$-dk/hafta olduğu ve bu bireylerin diğer katıIımcılara (rekreasyonel bisikletçi veya kontrol grubu) göre yaşam kalitesi alt grubu (fiziksel, psikolojik, sosyal, çevresel, ulusal çevre sağlığı, genel yaşam kalitesi ve sağlık) skorlarının daha yüksek olduğu görülmüştür. Yarışmacı bisikletçilerin istatistiksel açıdan psikolojik sağlık, sosyal sağlık ve genel yaşam kalitesi skorlarının diğer gruplara (rekreasyonel bisikletçiler ve kontrol) göre daha yüksek olduğu, ayrıca rekreasyonel bisikletçilerin kontrol grubuna göre daha yüksek fiziksel sağllik skoruna sahip olduğu saptanmışıı $(p<0.05)$.

Sonuç: Çalışma sonucunda haftada 7-13 saat aralı̆̆ında orta şiddetli aerobik egzersizin (2600-4800 MET-dk/hafta enerji harcaması) genel sağliğın korunmasını desteklediği ve yaşam kalitesi üzerine olumlu etkiler sağladığı bulunmuştur. Gelecek araştırmalarda egzersiz tipi, şiddeti ve sıklığının genel sağllk ve yaşam kalitesine etkilerini derinlemesine inceleyen çalışmalara intiyaç vardır.

\section{Anahtar Sözcükler: Aerobik egzersiz, sağlık, yaşam kalitesi}

\section{INTRODUCTION}

The physical activity has important roles in the advancement and protection of health (1). The World Health Organization (WHO) defined health as 'physical, mental, social and psychological well-being' (2). This valuable treasure of

ours is at risk with various conditions such as sedentary life. People who do physical activity less than 150 minutes in a week and sit or lay down more than seven hours in a day are known as sedentary (3). Sedentary lifestyle incre- 
ases risk for some chronic diseases such as cardiovascular diseases, hypertension, type 2 diabetes mellitus, several cancer types (colon, breast etc.), osteoporosis and depression (4). The relation between regular physical activity and life quality which has important effects on human health is a subject of interest. Some researchers tried to highlight this relation with different methods $(5,6)$. WHO defined life quality as humans' culture, mission, vision, life standards and fear perceptions which are related with habitation place (7). Life quality changes according to physical, psychological, social and environmental health status (8).

Life quality is among the core elements in the definition of health of the World Health Organization mentioned above. When the sub-titles of life quality are evaluated, it includes concepts such as the ability to maintain cognitive functions as well as mental, emotional and social functionality $(9,10)$. Knowing the factors that affect life quality and taking initiatives for improvement can help promote general health. Although it is known that exercise has positive effects on life quality, it is noteworthy that there is still lack of information regarding exercise type, intensity and dosage (11).

Regular physical activity has important effects on physical and mental health $(12,13)$. Out of many factors, depression lowers life quality. Regular physical activity has been reported to decrease depression symptoms up to $30 \%$ (13). Exercise has beneficial effects on social life as well. For instance, people can make friends and improve their social relations by joining exercise groups (14). Because of these beneficial effects, regular physical activity is suggested for all people to increase life quality $(8,12)$.

Endurance is defined as the ability to continue a physical action or exercise without getting tired for a long term (15). Circulatory and respiratory systems have important roles to provide oxygen and energy to muscle cells during the activity (16).

Long term regular physical activity improves cardiorespiratory status and oxygen using ability. Maximum oxygen consumption status, which is known as aerobic capacity, is an important indicator of physical endurance. Athletes who perform regular endurance type of exercise for a long term have higher aerobic capacities than others (17). Low aerobic capacity increases the incidence of coronary heart disease and all causes of mortality risk (18). Physical inactivity is the fourth important factor of the global mortality risk (19). There are some studies which are related with physical activity and life quality $(20,21)$. Physiological gains are achieved according to type of physical activity. The present study aimed to determine effects of moderate aerobic exercise on the life quality and general health.
In addition, the authors hypothesized that moderate intensity aerobic exercise may have beneficial effects (depending to dose-response relation) on the life quality and general health.

\section{MATERIAL and METHODS}

\section{Participants}

Fifty competitive cyclists (CC) (mean age 31.94 \pm 11.96 years) who regularly participate in the competitions organized by the North Cyprus cycling federation, 50 physically active recreational cyclist (RC) who regularly do cycling exercise voluntarily participated the study. The average training time of a competing cyclist was $13.33 \pm 7.24$ hours per week and the recreational cyclist was 7.24 \pm 4.5 hours per week. In addition, 50 sedentary adults (mean age $39.32 \pm 11.03$ years) who did not regularly engage in physical activity constituted the control group (CG) of the study. Due to cancellation of some of the competitions because of the pandemic conditions, the $\mathrm{CC}$ and the RC exercised at similar exercise loads (moderate intensity) for their own conditional capacity in this time course. This study was approved by the Near East University ethics committee (YDU/2020/86-1235).

\section{Data collection}

Due to the conditions arising from the Coronavirus Pandemic, an online interactive questionnaire was designed by the researchers. There were two sections of this online survey. First section was developed for the current study and aimed to determine participants' general background (age, gender, training times and frequencies etc.).

Second section was related to life quality and included 'World Health Organization Quality of Life Questionnaire Abbreviated Version' which was developed by WHO (22). The latter was validated for (Eser et al.) Turkish as WHOQOL-BREF-TR (23).

\section{World Health Organization Quality of Life Questionnaire} Abbreviated Version - WHOQOL-BREF-TR

WHOQOL-10o was taken as the basis to develop WHOQOLBREF. WHOQOL-100 includes six subgroups, 100 questions (22). The researchers used WHOQOL-BREF instead of WHOQOL-100 according to results of some studies. The Turkish version namely, WHOQOL-BREF-TR, consists of five subgroups (23). Table 1 depicts physical health, psychological health, social relationship, environment and national environmental health in 27 questions (in five-point Likert scale format) (24). All questions were related to the last 15 days. First point meant 'disagree' and fifth 'absolutely agree'. There was no maximum score nor an evaluation scale of WHOQOL-BREF-TR. Even though, if the scores of subgroups increase, participants' life quality increases $(23,24)$. 
Table 1. Contents of WHOQOL-BREF subgroups (24)

\begin{tabular}{|c|c|}
\hline $\begin{array}{r}\text { Subgroup } \\
\text { Physical health }\end{array}$ & $\begin{array}{l}\text { Content } \\
\text { Pain and discomfort, energy and fatigue, sexual activity, sleep and rest, sensory functions }\end{array}$ \\
\hline $\begin{array}{l}\text { Psychological } \\
\text { health }\end{array}$ & $\begin{array}{c}\text { Positive feelings, thinking, learning, memory and concentration, self-esteem, bodily image and appearance, negative } \\
\text { feelings }\end{array}$ \\
\hline Social relationships & Personal relationships, social support, activities as provider/supporter \\
\hline Environment & $\begin{array}{c}\text { Freedom, physical safety and security, home environment, work satisfaction, financial resources, health and social care: } \\
\text { accessibility and quality, opportunities for acquiring new information and skills, participation in and opportunities for } \\
\text { recreation/ leisure activities, physical environment, transport }\end{array}$ \\
\hline General & There are two general questions related with general health and quality of life. \\
\hline
\end{tabular}

* WHOQOL-BREF-TR includes one more question in National Environmental Health subgroup (23).

\section{Calculation of the Metabolic Equivalent Task (MET), Oxygen Consumption $\left(\mathrm{VO}_{2}\right)$ and Energy Expenditure During Physical Activity}

During the resting period, the estimated amount of oxygen consumption per body weight was accepted as 1 Metabolic Equivalent (MET) (3.5 ml/kg/min) (25).
For calculation of the weekly estimated MET value according to exercise dose, researchers used [6 METs`Mean weekly training time (min)] formula. Moderate intensity cycling on the straight road equals to 6 METs value (26). For calculation of the estimated weekly energy expenditure during the activity, researchers used [(6 MET* $3.5^{\star}$ Body weight $(\mathrm{kg})) / 1000]{ }^{\star}{ }^{\star}$ time $(\mathrm{min})$ formula which was developed by American College of Sport Medicine (27). Table 2 shows these formulas.

Table 2. Some formulas which were used for calculations $(26,27)$

Estimated resting $\mathrm{VO}_{2}\left(\mathrm{ml} \cdot \mathrm{min}^{-1} \cdot \mathrm{kg}^{-1}\right)$

Weekly estimated MET value achieved in exercise ( $\mathrm{min} /$ week)

Weekly exercise related oxygen use $\left(\mathrm{VO}_{2}\right.$ /liter)

Weekly energy expenditure related to exercise (kcal)

\section{Statistical analysis}

Statistical Package for the Social Science-version 18.0 was used for analysis. Number (n) and percentage (\%) of qualitative data and mean $(\bar{x})$ and standard deviation (SD) of quantitative data were determined with descriptive statistics. In addition, comparison of the data was evaluated with One Way ANOVA, Post Hoc-Bonferroni and Pearson Chisquare tests. $\mathrm{p}<0.05$ shows statistical significance.

\section{RESULTS}

This study was conducted with 150 voluntary participants (79.3\% male). Each group included 50 people.
Body weight $(B W)^{*} 3.5\left(\mathrm{ml} \cdot \mathrm{min}^{-1} \cdot \mathrm{kg}^{-1}\right)$ $6 \mathrm{MET}^{*}$ Weekly exercise duration (min) $6 \mathrm{MET}^{*} 3.5^{*}$ Weekly exercise duration (min) [(6 MET*3.5*BW (kg))/1000] * 5 * time (min)

Looking at the health conditions, the CC had a tendency of lower range of health problems (though not reaching significance). These ranges were found to be $10.0 \%, 20.0 \%$ and $22.0 \%$ (for CC, RC and CG) respectively. Mean body weight was found as $75.20 \pm 10.29 \mathrm{~kg}$ for CC, as $80.23 \pm 10.85 \mathrm{~kg}$ for RC and as $70.60 \pm 14.77 \mathrm{~kg}$ for CG (Table 3) (p>0.05 for all parameters). CC trained for $13.33 \pm 6.70$ hours in a week and RC trained for $7.24 \pm 4.50$ hours. Mean MET value was found to be $4798 \mathrm{MET}$-min/week in CC and $2607 \mathrm{MET}$-min/week in RC. In addition, CC had 21.7 liter/kg oxygen consumption in a week and RC had 8.74 liter/kg (Table 4).

\section{Table 3. Participants' general background and anthropometric measurements}

\begin{tabular}{|c|c|c|c|c|c|c|c|c|}
\hline \multirow[b]{2}{*}{ Gender } & \multicolumn{2}{|c|}{$\begin{array}{l}\text { Competitive cyclist } \\
\text { (n: 50) }\end{array}$} & \multicolumn{2}{|c|}{$\begin{array}{l}\text { Recreational cyclist } \\
\text { (n: 50) }\end{array}$} & \multicolumn{2}{|c|}{$\begin{array}{l}\text { Control group } \\
\text { (n: 50) }\end{array}$} & \multicolumn{2}{|c|}{$\begin{array}{c}\text { Total } \\
\text { (n: 150) }\end{array}$} \\
\hline & $n$ & $\%$ & $\mathbf{n}$ & $\%$ & $\mathrm{n}$ & $\%$ & $\mathbf{n}$ & $\%$ \\
\hline Male & 50 & 100.0 & 44 & 88.0 & 25 & 50.0 & 119 & 79.3 \\
\hline Female & 0 & 0.0 & 6 & 12.0 & 25 & 50.0 & 31 & 20.7 \\
\hline Total & 50 & 100.0 & 50 & 100.0 & 50 & 100.0 & 150 & 100.0 \\
\hline & \multicolumn{2}{|c|}{$\begin{array}{c}\bar{x} \pm \text { SD } \\
(\min -\max )\end{array}$} & \multicolumn{2}{|c|}{$\begin{array}{c}\bar{x} \pm \text { SD } \\
(\min -\max )\end{array}$} & \multicolumn{2}{|c|}{$\begin{array}{c}\bar{x} \pm S D \\
(\min -\max )\end{array}$} & \multicolumn{2}{|c|}{$\begin{array}{c}\bar{x} \pm S D \\
(\min -\max )\end{array}$} \\
\hline Age (years) & \multicolumn{2}{|c|}{$\begin{array}{l}31.94 \pm 11.96 \\
(19.0-64.0)\end{array}$} & \multicolumn{2}{|c|}{$36.84 \pm 11.28$} & \multicolumn{2}{|c|}{$39.32 \pm 11.03$} & \multicolumn{2}{|c|}{$36.03 \pm 11.76$} \\
\hline Body weight (kg) & \multicolumn{2}{|c|}{$75.20 \pm 10.29$} & & $\begin{array}{r}0.85 \\
10.0)\end{array}$ & & $\begin{array}{l} \pm 14.77 \\
-93.0)\end{array}$ & \multicolumn{2}{|c|}{$75.34 \pm 12.68$} \\
\hline Body height (cm) & \multicolumn{2}{|c|}{$176.02 \pm 6.16$} & \multicolumn{2}{|c|}{$174.78 \pm 7.45$} & & $\begin{array}{l}2 \pm 8.81 \\
-184.0)\end{array}$ & \multicolumn{2}{|c|}{ (142.0-190.0) } \\
\hline
\end{tabular}


Table 3. Participants' general background and anthropometric measurements

\begin{tabular}{|c|c|c|c|c|c|c|c|c|}
\hline \multirow[b]{2}{*}{ Gender } & \multicolumn{2}{|c|}{$\begin{array}{l}\text { Competitive cyclist } \\
\text { (n: 50) }\end{array}$} & \multicolumn{2}{|c|}{$\begin{array}{l}\text { Recreational cyclist } \\
(n: 50)\end{array}$} & \multicolumn{2}{|c|}{$\begin{array}{l}\text { Control group } \\
\text { (n: 50) }\end{array}$} & \multicolumn{2}{|c|}{$\begin{array}{l}\text { Total } \\
(n: 150)\end{array}$} \\
\hline & $\mathrm{n}$ & $\%$ & $\mathbf{n}$ & $\%$ & $\mathbf{n}$ & $\%$ & n & $\%$ \\
\hline Health problem & $\mathbf{n}$ & $\%$ & $\mathbf{n}$ & $\%$ & n & $\%$ & n & $\%$ \\
\hline No & 45 & 90.0 & 40 & 80.0 & 39 & 78.0 & 124 & 82.6 \\
\hline Yes & 5 & 10.0 & 10 & 20.0 & 11 & 22.0 & 26 & 17.3 \\
\hline Total & 50 & 100.0 & 50 & 100.0 & 50 & 100.0 & 150 & 100.0 \\
\hline
\end{tabular}

Table 4. Physical activity related information

\begin{tabular}{|c|c|c|}
\hline Training age (years) & $\begin{array}{c}\text { Competitive cyclists } \\
\text { (n: } 50) \\
\overline{\boldsymbol{x}} \pm \mathrm{SD} \\
11.18 \pm 10.47\end{array}$ & $\begin{array}{c}\text { Recreational cyclists } \\
\text { (n: } 50 \text { ) } \\
\overline{\boldsymbol{x}} \pm \text { SD } \\
10.16 \pm 9.93\end{array}$ \\
\hline Training frequency (unit/week) & $4.96 \pm 1.47$ & $3.94 \pm 1.76$ \\
\hline Weekly training time (hours) & $13.33 \pm 6.70$ & $7.24 \pm 4.50$ \\
\hline Resting $\mathrm{VO}_{2}(\mathrm{ml} / \mathrm{kg} / \mathrm{min})$ & 263 & 280.80 \\
\hline MET value achieved in weekly exercise ( $\mathrm{min} /$ week) & 4798 & 2607 \\
\hline Oxygen use in weekly exercise $\left(\mathrm{VO}_{2} /\right.$ liter/ $\left.\mathrm{kg}\right)$ & 21.70 & 8.74 \\
\hline Estimated weekly energy expenditure during exercise (kcal) & 6315.20 & 3661.50 \\
\hline
\end{tabular}

When we compared groups, there were statistically significant differences for physical health $(\mathrm{p}=0.01)$, psychological health $(p=0.001)$, social relationships $(p=0.01)$ and life $q u-$ ality $(p=0.01)$ scores. According to the Post Hoc test, RC had a higher physical health score than CG $(\mathrm{p}=0.01)$. Psychological health score was found to be higher in CC ( $p=$
0.003) and $\mathrm{RC}(\mathrm{p}=0.005)$. On the other hand, social relationship $(p=0.02)$ and life quality scores $(p=0.01)$ were higher in CC than CG. In addition, CC had the highest score for national environmental health and health subgroups (Table 5). Figure 1 shows differences between groups clearly.

Table 5. Quality of life scores of participants

\begin{tabular}{|c|c|c|c|c|c|}
\hline & $\begin{array}{c}\text { CC } \\
\text { (n: 50) } \\
\bar{x} \pm S D\end{array}$ & $\begin{array}{c}\text { RC } \\
\text { (n: 50) } \\
\bar{x} \pm \text { SD }\end{array}$ & $\begin{array}{c}\text { CG } \\
(n: 50) \\
\bar{x} \pm S D\end{array}$ & $\begin{array}{c}\text { Total } \\
\text { (n: 150) } \\
\overline{\boldsymbol{x}} \pm \text { SD }\end{array}$ & $\mathbf{p}$ \\
\hline Physical health & $16.34 \pm 2.00$ & $16.58 \pm 1.78$ & $15.26 \pm 2.90$ & $16.06 \pm 2.33$ & 0.01 \\
\hline Psychological health & $16.25 \pm 2.28$ & $16.16 \pm 2.41$ & $14.46 \pm 3.09$ & $15.62 \pm 2.73$ & 0.001 \\
\hline Social relationships & $16.08 \pm 2.76$ & $15.86 \pm 2.54$ & $14.48 \pm 3.60$ & $15.47 \pm 3.06$ & 0.01 \\
\hline Environment & $15.46 \pm 2.27$ & $15.09 \pm 2.53$ & $14.68 \pm 2.82$ & $15.07 \pm 2.55$ & 0.31 \\
\hline National environmental health & $15.58 \pm 2.12$ & $15.18 \pm 2.36$ & $14.68 \pm 2.69$ & $15.14 \pm 2.41$ & 0.17 \\
\hline Life quality score & $3.92 \pm 0.85$ & $3.82 \pm 0.82$ & $3.38 \pm 1.10$ & $3.70 \pm 0.95$ & 0.01 \\
\hline Health score & $4.08 \pm 0.92$ & $4.04 \pm 0.85$ & $3.68 \pm 1.20$ & $3.93 \pm 1.01$ & 0.09 \\
\hline
\end{tabular}

p: One Way ANOVA

$\mathrm{p}<0.05$ : Statistically significance

Bonferroni Post-Hoc test: Physical health [RC-CG (p: 0.01)], psychological health [CC-CG (p: 0.003) and RC-CG (p: 0.005)], social health [CC-CG (p: 0.02)] and life quality score [CC-CG (p: 0.01)]

\section{DISCUSSION}

The present study aimed to determine the relation between moderate aerobic exercise and life quality. According to results, all subgroup scores of WHOQOL-BREF-TR except environmental and health subgroups were found to be higher in study groups (CC and RC) than control group. There was a significant relation between physical endurance status and life quality.

Pucci et al (2012) reported the relation between physical activity and life quality with WHOQOL. Their findings were similar to the present study. When physical activity level increased, WHOQOL scores increased, as well (28).

Gill et al (2013) conducted a study on 142 university students to investigate the relationship between physical acti- vity and quality of life and determined that the contributions of physical activity had a positive effect not only on physical but also on all components of quality of life (29). In the study of Tanimaru et al (2016) on baseball players, they found that the quality of life of the athletes was at a satisfactory level (30). Dall' Agnol et al (2017) used same questionnaire with present study and found higher scores in physical and psychological subgroups for athletes (31). Omorou et al (2013) reported that physical, psychological and social relationship scores were higher in participants who had high level of physical activity (32). In another study which aimed to determine the relation between exercise and life quality, physically active participants had higher life quality scores than control group (sedentary adults) (33). Snyder et al (2010) compared active and non-active 
In this prospect, indeed cycling has important roles on the life quality due to its benefit of psychological and environmental effects (37). According to these similar results, we can say that regular physical activity has a significant and affirmative role on the general health, life quality and their subcomponents. As a result of the study, it was determined that the physical health scores of recreational cyclists and competitive cyclists were at similar levels, while the numerical values were higher in recreational cyclists.

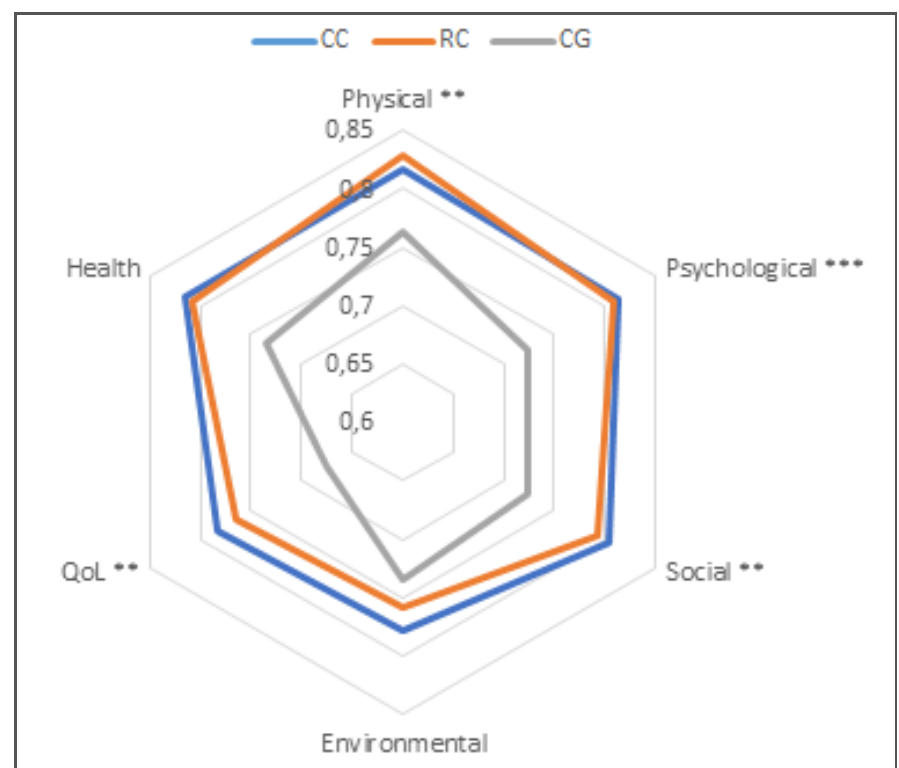

Figure 1. Modified Quality of Life Scores of Study Groups

CC: Competitive Cyclist. RC: Recreational Cyclist. CG: Control Group. The parameters were obtained from the applied tests as: Physical health, Psychological health, Social relationships, National environmental health, Qol: Quality of life score and health score. Scores were reformatted in regard to their respective percentages to better visualize in the radar plot.

These findings suggest that exercise may create different perceptions on physical health when applied for health purposes or for competition purposes. In addition, dose of the exercise is a very important factor; such that extreme physical activity may increase risk of some health problems such as myocardial infarction, coronary artery diseases, eating disorders and injuries etc. (38). On the other hand, Defina et al (2019) reported that all-cause mortality risk was not increased for the athletes who had high intensity training (1000o MET-min/week) (39). In another study it was showed that cycling decreased all-cause mortality risk for healthy participants who had 675 MET-min/week (40).

In the present study, competitive cyclist had 4798 METmin/week and recreational cyclist had 2607 MET-min/week. The energy expenditure values of the specified exercise contribute to the fat burning levels and weight control of the individuals. Having a high perception of physical appearance of individuals can provide positive contributions on the sub-title of quality of life and social behavior. The cur- rent study may provide guidance for future research to determine effects of indoor and outdoor sport branches together on physical endurance status.

There were some limitations of this study. It was conducted in 2020-2021, during COVID-19 pandemic. Thus, researchers could not determine cyclist' exercise capacity in laboratory conditions. Classification of physical activity dosage was determined with their training frequencies in a week and the purpose training (competitive/recreational).

\section{CONCLUSION}

A positive relationship between physical activity and life quality has been documented. Moderate aerobic exercise for 7-13 hours a week (2600-480o MET-min/week energy expenditure) supports the protection of general health and has positive effects on life quality. In future research, there is a need to examine the effects of exercise type, intensity, frequency and dosage on general health and life quality.

\section{Ethics Committee Approval / Etik Komite Onayı}

The approval for this study was obtained from Institutional Ethics Committee of Near East University, Nicosia, Turkish Republic of Northern Cyprus (Decision no: YDU/2020/86-1235 Date: 24.12.2020).

\section{Conflict of Interest / Çıkar Çatışması}

The authors declared no conflicts of interest with respect to authorship and/or publication of the article.

\section{Financial Disclosure / Finansal Destek}

The authors received no financial support for the research and/or publication of this article.

\section{Author Contributions / Yazar Katkıları}

Concept DS, TD, EG, AO; Design DS, TD, EG, AO; Supervision AO; Materials DS, TD, EG, AO; Data Collection and/or Processing DS, TD, EG, AO; Analysis and Interpretation DS, TD, EG, AO; Literature Review DS, TD, EG, AO; Writing Manuscript DS, TD, EG, AO; Critical Reviews DS, TD, EG, AO

\section{REFERENCES}

1. World Health Organization [Internet]. Health Education and Health Promotion Unit. c2003[cited 2021 March 16] Available from: https://apps.who.int/iris/handle/10665/67796.

2. World Health Organization [Internet]. Constitution. [cited 2021 March 16] Available from:https://www.who.int/about/who-we-are/constitution\#: :text=Health\%20is\%20a\%20 state\%20of.belief\%2C\%20economic\%20or\%20 social\%20condition.

3. Thivel D, Tremblay A, Genin PM, Panahi S, Rivière D, Duclos M. Physical activity, inactivity and sedentary behaviors: Definitions and implications in occupational health. Front Public Health. 2018;6:288.

4. Malmberg J, Miilunpalo S, Pasanen M, Vuori I, Oja P. Characteristics of leisure time physical activity associated with risk of decline in perceived health-a 10-year follow-up of middle-aged and elderly men and women. Prev Med. 2005;41(1):141-50.

5. Cooney G, Dwan K, Mead G. Exercise for depression. JAMA. 2014;311(23):2432-3.

6. Elavsky S. Longitudinal examination of the exercise and self-esteem model in middle-aged women. J Sport Exerc Psychol. 2010;32(6):862-80.

7. World Health Organization [Internet]. WHOQOL: Measuring Quality of Life. c2012- [cited 2021 April 23] Available from:https://www.who.int/tools/whoqol\#: :text=WH0\%20defines\%20 Quality\%20of\%20Life.\%2C\%20expectations \%2C\%20 standards\%20and\%20concerns.

8. Georgian B, Lorand B. The influence of leisure sports activities on social health in adults. SpringerPlus. 2016;5:1647.

9. Appelqvist-Schmidlechner K, Kyröläinen H, Häkkinen A, Vasankari T, Mäntysaari M, Honkanen T, et al. Childhood sports participation is associated with health-related quality of life in young men: A retrospective cross-sectional study. Front Sports Act Living. 2021;3(642993):110 . 
10. Bize R, Johnson JA, Plotnikoff RC. Physical activity level and health-related quality of life in the general adult population: a systematic review. Prev Med. 2007;45(6):401-15.

11. Eime RM, Young JA, Harvey JT, Charity MJ, Payne WR. A systematic review of the psychological and social benefits of participation in sport for children and adolescents: informing development of a conceptual model of health through sport. Int J Behav Nutr Phys Act. 2013;10(1):1-21.

12. Abou Elmagd M. Benefits, need and importance of daily exercise. IJPESH. 2016;3(5):22-7.

13. Herring MP, Puetz TW, O'Connor PJ, Dishman RK. Effect of exercise training on depressive symptoms among patients with a chronic illness: a systematic review and meta-analysis of randomized controlled trials. Arch Intern Med. 2012;172(2):101-11.

14. Unger JB, Johnson CA. Social relationships and physical activity in health club members. Am J Health Promot.1995;9(5):340-3.

15. Bompa TO, Buzzichelli C, Periodization: Theory and Methodology of Training. $6^{\text {th }}$ Ed. Champaign: Human Kinetics;2018.

16. Morici G, Gruttad'Auria Cl, Baiamonte P, Mazzuca E, Castrogiovanni A, Bonsignore MR. Endurance training: is it bad for you? Breathe. 2016; 12(2):140-7.

17. Ventura-Clapier R, Mettauer B, Bigard X. Beneficial effects of endurance training on cardiac and skeletal muscle energy metabolism in heart failure. Cardiovasc Res. 2007;73(1): 10-8.

18. Kodama S, Saito K, Tanaka S, Maki M, Yachi Y, Asumi M, et al. Cardiorespiratory fitness as a quantitative predictor of all-cause mortality and cardiovascular events in healthy men and women: a meta-analysis. JAMA.2009; 301(19):2024-35.

19. World Health Organization [Internet]. Global health risks. Mortality and burden of disease attributable to selected major risks. Mortality and burden of disease attributable to selected major risks. WHO Library Cataloguing-in-Publication Data; c2009- [cited 2021 April 17] Available from:https://www.who.int/healthinfo/global_burden_disease/GlobalHealthRisks_report_full.pdf.

20. Bize R, Johnson JA, Plotnikoff RC. Physical activity level and health-related quality of life in the general adult population: a systematic review. Prev Med. 2007; 45(6):401-15.

21. Kallings LV, Leijon M, Hellénius ML, Ståhle A. Physical activity on prescription in primary health care: a follow-up of physical activity level and quality of life. Scand J Med Sci Sports. 2008; 18(2):154-61.

22. World Health Organization [Internet]. The World Health Organization Quality of Life (WHOQOL). c2012- [cited 2021 March 17] Available from: https://www.who.int/publications/i/item/WHO-HIS-HSI-Rev.2012.03.

23. Eser E, Fidaner H, Fidaner C, Eser SY, Elbi H, Göker E. WHOQOL100 ve WHOQOL-BREF'in psikometrik özellikleri. 3P Dergisi. 1999;7: 23-40.

24. World Health Organization [Internet]. WHOQOL BREF. Introduction. Administration. scoring and generic version of the assessment. c1996- [cited 2021 March 17] Available from:https://www.who.int/mental_health/media/en/76.pdf.
25. Gunga HC. Human physiology in extreme environments: Exercise physiology. $2^{\text {nd }} \mathrm{Ed}$. London: Elsevier;2020, p.81-122.

26. Haskell WL, Lee IM, Pate RR, Powell KE, Blair SN. Franklin BA, et al. Physical activity and public health: updated recommendation for adults from the American College of Sports Medicine and the American Heart Association. Circulation. 2007;116(9):1081-93.

27. ACSM's health-related physical fitness assessment manual. $4^{\text {th }}$ Ed. Philedelphia:Lippincott Williams \& Wilkins; 2013

28. Pucci G, Reis RS, Rech CR, Hallal PC. Quality of life and physical activity among adults: Population-based study in Brazilian adults. Qual Life Res. 2012; 21(9):1537-43.

29. Gill DL, Hammond CC, Reifsteck EJ, Jehu CM, Williams RA, Adams MM, et al. Physical activity and quality of life. J Prev Med Public Health. 2013; 46(Suppl 1):28-34.

30. Tanimaru JH, Dos Santos ALP. Study on the quality of life at a baseball performance center. $J$ Phys Educ Sport.2016;16(2):365-73.

31. Dall'Agnol C, Silva R, Del Vecchio F. Quality of life of male amateur athletes from Pelotas, Brazil. Rev Bras Ativ Fís Saúde. 2017;22(2):147-54.

32. Omorou YA, Erpelding ML, Escalon H, Vuillemin A. Contribution of taking part in sport to the association between physical activity and quality of life. Qual Life Res. 2013;22(8):2021-9.

33. Sguizzatto GT, Garcez-Leme LE, Casimiro L. Evaluation of the quality of life among elderly female athletes. Sao Paulo Med J. 2006;124(5):304-5.

34. Snyder AR, Martinez JC, Bay RC, Parsons JT, Sauers EL, McLeod TCV. Health-related quality of life differs between adolescent athletes and adolescent nonathletes. J Sport Rehabil. 2010;19(3):237-48

35. Shibata A, Oka K, Nakamura Y, Muraoka I. Recommended level of physical activity and healthrelated quality of life among Japanese adults. Health Qual Life Outcomes. 2007;5(1):18.

36. Crane M, Rissel C, Standen C, Greaves S. Associations between the frequency of cycling and domains of quality of life. Health Promot J Austr. 2014;25(3):182-5.

37. Park S, Yoon $\mathrm{H}, \mathrm{Koo} \mathrm{C}$, Lee WS. Role of the leisure attributes of shared bicycles in promoting leisure benefits and quality of life. Sustainability. 2021;13(2):739.

38. Polat MG. Fiziksel Aktivite/Egzersizin Riskleri. Türkiye Klinikleri J Physiother Rehabil-Special Topics. 2016;2(1):24-9.

39. De Fina LF, Wright BB, Willis BL,Leonard D, Farrell SW, Pavlovic A et al. Athletes Performing Extraordinary Physical Activity (>10,000 MET·Min/Week) at No Greater Risk of All-Cause or Cardiovascular Disease Mortality. Circulation. 2019;140(Suppl 1): A14863

40. Kelly P, Kahlmeier S, Götschi T, Orsini N, Richards J, Roberts N, et al. Systematic review and meta-analysis of reduction in all-cause mortality from walking and cycling and shape of dose response relationship. Int J Behav Nutr Phys Act.2014;11:132 